\title{
Social and Economic Conflicts Influencing Students' Participation in Secondary School Education in Kakamega County, Kenya
}

\author{
Philip Wanjala Mukonyi ${ }^{{ }^{*}} \quad$ Crispinous Iteyo ${ }^{2}$ \\ 1.Department of Educational Foundations, Masinde Muliro University of Science and Technology \\ P.O. Box 190 - 50100 Kakamega, Kenya \\ 2.Department of Peace and Conflict Studies, Masinde Muliro University of Science and Technology \\ P.O. Box 190 - 50100 Kakamega, Kenya
}

\begin{abstract}
The importance of education in contemporary world order cannot be gainsaid. Education is the first step towards human empowerment and plays vital role in the development of human capital that is imperative in the modern technological and knowledge economy. This study set out to investigate the nature of social and economic conflicts affecting students' participation in secondary school education in Kakamega County. It used a conceptual model where social and economic conflicts as represented by poverty and drug and substance abuse on one side and effects on students' participation in secondary school education on the other. The measurable indicators for participation were enrolment, retention, progression and completion of secondary school education. The research design adopted for this study was ex post facto in which cross cultural survey and correlational design were used. The study population was 20274 students in county and sub county schools in the three sampled sub counties of Kakamega North, Mumias East and Kakamega East; 63 principals, 63 guiding and counselling teachers, parents and guardians, religious leaders, chiefs, NG-CDF managers and Sub County Directors of education. Purposive sampling was used to select the three sub counties, stratified random sampling was used to select the schools while purposive, simple random and stratified random sampling were used to identify all other respondents. Data were collected using questionnaires, interviews schedules and FGD. Data were analysed using the SPSS programme to identify the nature of social and economic conflicts and determine their prevalence within the study area. Correlation coefficients were used to assess the relationship between independent variables and dependent variables. The multiple regression analysis was used to assess the effect of independent variables on dependent variable. The findings indicated that social and economic conflicts were prevalent in the study area and significantly affected students' participation in secondary school education in Kakamega County.
\end{abstract}

Keywords: social and economic conflicts, participation, secondary school

DOI: $10.7176 / \mathrm{JEP} / 11-14-13$

Publication date:May $31^{\text {st }} 2020$

\section{Background}

The importance of education in contemporary world order cannot be gainsaid. In the current era of globalization and technological revolution, education is indeed a first and crucial rung in human empowerment. It plays a pivotal role in the development of human capital and is invariably linked with an individual's well-being and opportunities for better living (Geremew and Dhufera, 2015). Education basically entails the acquisition of knowledge and skills that enable individuals to increase their productive capacity and improve their quality of life. The increase in productivity, consequently, expands the sources of earning thereby leading to national economic growth (Farooq, 2015). Education is recognised as a fundamental human right as enshrined in the 1948 United Nations Declaration on Human Rights (UDHR) article 26 and consequent international protocols. Low levels of education have been shown to positively correlate with high mortality, fertility, and poverty at both household and national levels (UNESCO 2010; Tilak 2007).

Many factors, for example, individual and household characteristics, socio-economic status, school related factors and government policies, have substantial impact on school participation and academic performance of students (Dayioglu and Türüt -Asik, 2004; Farooq, 2011). According to Ahmad and Khan (2012), one's educational success depends very strongly on social economic status of the parent and the learner. Considine and Zappala (2002) argue that families where the parents are advantaged socially, educationally and economically foster a high level of success in their children.

Studies have also yielded strong evidence of the impact of conflicts on the quality of education using different educational outcomes such as school enrolment, school attendance and school attainment (Buvinic, 2013; Leon, 2012; Justino, 2012; UNESCO, 2011). The prevalence of social, political and economic conflicts in the developing world has attracted considerable research within the development and socio-economics literature. The role of conflict in militating against the achievement of Education for All (EFA) is of central concern as conflict has been considered a cause of regressive growth that has exacerbated the gap between developed and developing world. Whereas education is expected to be an instrument towards egalitarianism, this expectation has been compromised by differences in socioeconomic background which results in significant difference in child education outcomes. 
Children from background plagued by social and economic conflicts may not attain same education success as compared to those from a stable background.

Students experience variety of violence at home, school, and streets among other places. Students who experience or are vulnerable to extreme violence exhibit diminished educational achievement and normal life. Studies in Africa have documented cases of school girls who leave school, or skip particular classes because a certain teacher has sexually molested them (Chege and Mati, 1997). A qualitative study in Addis Ababa, Ethiopia, found that bullying and attempted rape were among the factors responsible for low female enrolment rates and high dropout rates from schools, (Brock and Cammish, 1997). Chege (2007) noted that violence against girls manifests its effects in low enrolment of girls in schools, comparatively poor performance at school, high dropout rates, teenage pregnancy, teenage marriage, increasing rates of HIV and AIDS in the 15-24 year old age group and psychological trauma.

Conflicts in the family and community have resulted to abuse of drugs and prohibited substances by students. Dysfunctional families are largely due to unstable low income, poor marital relationship, conflicts, divorce, separation, single parenthood, long working hours of family members, limited family time, ineffective communication, easy access to drugs within immediate neighbourhood, absence of social cohesion, undesirable peer influence, inter-generational addiction results to drug and substance abuse (Simatwa, 2014). According to Sun (2001), children in dysfunctional and unstable families exhibit more academic, psychological, behavioural, and drug-related problems than children from families that are largely stable. Parental conflicts predict externalizing behaviour such as tobacco use, alcohol consumption and marijuana use. As parents separate due to conflicts, adolescent use of illegal drugs increases (Kathleen and Hilary, 2002).

\section{Social and economic conflicts and participation in secondary school education}

This paper reviewed literature social and economic conflicts and how they impacted on students' participation in secondary school education.

\subsection{Poverty}

Income poverty is the condition of not having enough income to meet basic needs for food, clothing, and shelter. Because children are dependent on others, they enter or avoid poverty by virtue of their family's economic circumstances. Children cannot alter family conditions by themselves, at least until they approach adulthood. Studies and reports have examined the detrimental effects of poverty on the well-being of children. Most agree that poverty impacts harshly on children within their various contexts, be it at home, in school, in their neighbourhoods, and in their communities (Ganga \& Chinyoka, 2010). The indicators of the extent of poverty include sub-standard housing, homelessness, inadequate nutrition and food insecurity, lack of access to health care, unsafe neighbourhoods, and under-resourced schools, all of which adversely impact on the holistic development of children (Abebe, 2009).

Poverty, whether absolute or relative, is associated with a lack of income, and is associated with the failure to attain one's capabilities. It can be chronic or temporary, and is sometimes closely related or associated with inequality (Chireshe, 2010; Emwawu \& Osujo, 2010). Absolute poverty, the complete lack of resources, hampers learning in developing countries because of poor nutrition and health. The home environment is characterised by lack of adequate nutrition, lack of learning accoutrements, inadequate lighting and low education of parents (Neuman, 2009). Poverty discourages enrolment in school and negatively impacts on survival to higher grades, as well as reducing learning in schools (Robertson, 2011).

Children from poor and needy backgrounds were also found to be at a greater risk of several negative outcomes, such as poor academic achievement, school drop-out, abuse, neglect, behavioural and socio-emotional problems, physical health problems, and developmental delays (Kent, 2006; Moore, 2009; Chilton, 2007).

There is abundant literature that addresses the relationship between poverty and the psychosocial development of the child. However, not much has been written focusing on poverty and participation in secondary school education in Kenya. Another key weakness is the fact that most of the studies were carried out in developed countries where not so many children are affected by extreme poverty (Manwa, 2010). A definition of poverty in the west, with welfare safety nets, may not have the same meaning and effect as in the developing world.

While the literature on the effects of poverty on children and education is available, many studies lack the precision necessary to allow researchers to identify the real effects on children of the many aspects associated with poverty. Understanding of the relationships between poverty indicators and participation in education would lead to the formulation and implementation of ameliorative policy frameworks. Most countries were hopeful that opportunities provided by strengthened democratic governance, and improving economies would accelerate progress. However, poverty levels still remain high. On becoming a republic in 1964, emerging political leaders in independent Kenya vowed to eradicate poverty, disease and illiteracy. Today the proportion of the population living on less than one US dollar a day, that is the poverty line, is higher than ever before (Sisule, 2001). With high poverty levels, compounded by economic crisis, prevalence of HIV and AIDS pandemic, the attainment of 
Education For All by 2015 remained elusive. Poverty has been recognized as one of the factors that affect education. 2.1.1 Poverty and schooling

Educational attainment is well recognized as a powerful predictor of experiences in later life. A comprehensive review of the relationship between parental income and school attainment, in USA in 1994, concluded that poverty limited school achievement but that the effect of income on the number of school years completed was small. In general, the studies suggested that a $10 \%$ increase in family income is associated with a $0.2 \%$ to $2 \%$ increase in the number of school years completed.

Sum and Fogg (2001, as cited in Bergeson, 2006) found that students from poor backgrounds and households were ranked in the 19th percentile on assessments, while students from a mid-upper income family were ranked in the 66th percentile on assessments. In one study, $43.5 \%$ of low-income students did not successfully meet any of the required subject area assessments, while only 13.2\% of low-income students met all of the required subject area assessments (Bergeson, 2006). Similar studies found comparable results (Bergeson, 2006). Children from very poor households with an income below $50 \%$ of the poverty line, scored 7 to 12 points lower than children from non-poor households, while children from poor households, with an income from $50 \%$ to $100 \%$ of the poverty line, scored 4 to 7 points lower (Smith, Lowers\& Larkin, 2009). Mayer (2007) tested students in reading and mathematics prior to an increase in income, followed by a post-test after the increase in income. The findings indicated that the effect on the reading scores ranged from a small negative effect to a small positive effect, while the effects on the scores in mathematics were slightly bigger (Mayer, 2007).

While it may be true that children from poor and needy households tend to perform poorly in comparison to children from affluent backgrounds, in some situations some children from poor backgrounds defied the odds and performed very well. Rutter (2008) as cited in Bernard, (2012) indicated that children who have resilience tend to do better in some risky contexts when compared to children without protective factors in the same contexts. This shows that not all children from low socio-economic backgrounds will perform poorly at school. However, this is not a justification to expose a child to any risk, because there are girl children who do better when not exposed to high levels of poverty or adversity (Ong, Bergeman, Bisconti, \& Wallace, 2006; Tugade, Fredrickson, \& Barrett, 2004).

Not only is children's education influenced by the personal, educational background of their parents, but these personal experiences are highly connected to their economic background. Along with their ability to educate their offspring, the economic status of people plays a substantial role in their own education. Parents with lower incomes often have to work longer hours to earn their small salaries. This leaves less time for them to spend reading to their children and getting more involved in their kids' learning process. There is also, typically, more conflict in homes of lower incomes because there are more tensions caused by stress within the family. Sclafani argues that:

Parents who expressed more conflict at home over child rearing and family rules failed to provide a consistent message to their children, resulting in poorer school performance. Parents' behaviour that was indifferent or neglectful also was correlated with negative school outcomes. (Sclafani, 2010: 87)

It may not always be true that lower income parents neglect their children's education, but it is easy to slip into that stereotype under extreme pressure. There are also conflicts that arise between parents and teachers centred on non-provision of adequate learning and support requirements.

Caro (2009) found a significant positive correlation between family socio-economic status and academic achievement. Chen (2009) also posited that parental education was a key determinant of student's achievement. They noted that there was gap in academic achievement between students from high and low socio-economic status families. They stressed further that because children from low socio-economic status had relatively poor skills, they were prone to leave school early and less likely to gain admission to college. Udida, Ukway and Ogodo (2012) also agreed that family characteristics were major source of disparity in student's educational outcomes. They further observed that students' academic performance was influenced by the socio-economic background of their parents. The difference in performance was largely explained by difference in support from parents.

King'ori (2015) conducted a study on the influence of the hidden costs on students' participation in secondary school education in Kikuyu sub county of Kenya. He set to investigate why students dropped out of secondary school or did not enrol at all when the government was supporting education through Free Day Secondary Education funding. Using a sample of 300 students, 135 teachers and 14 principals from 28 secondary schools, King'ori established that on average $5.7 \%$ of any cohort enrolled in form one did not persist up to form four. He found out that the hidden costs of education namely lunch charges, Parents Association (PA) project development levies, uniform fees and other opportunity costs like looking for petty employment to earn some money for food, were largely responsible for students dropping out from secondary schools in Kikuyu Sub County. Dropping out of school was therefore seen as an effect of economic challenges. This study was particularly relevant to the current one in Kakamega County.

Ngwacho, (2011) carried out a study on the hidden costs of Free Primary Education and their implications on enrolment in Kisii Central sub county. He set out to identify the hidden costs of primary education and their impact 
on participation in primary education. He obtained responses from parents which indicated that they bore more than $100 \%$ of what the government was providing as subsidy. The cost met by parents ranged from meals, uniform, transport, activity to exercise books, homework, PA teachers emoluments and examinations. It was found that up wards of $11.9 \%$ of the students dropped out of primary schools during the study period (Ngwacho, 2011).

\subsubsection{Drug and substance abuse}

Drug abuse is the use of drugs for purposes other than the intended therapeutic reasons or purposes for which they were intended, thus affecting the individual in a negative way socially, cognitively and physically (Kuria 1996). Social effects may be reflected in an individual's enhanced tendency to engage in conflicts with friends, teachers, and school authorities. Cognitive effects relate to the individual's lack of concentration on academic work and memory loss. Lewinsohn (2007) defines a drug as any product other than food or water that affects the way people feel, think, see, and behave. It is a substance that due to its chemical nature affects physical, mental and emotional functioning of the human body. It can enter the body through chewing, swallowing/ingestion, inhaling, smoking, drinking, and/or rubbing on the skin or injection. The most commonly abused substances include alcohol, marijuana and tobacco.

The World Health Organisation (WHO) defines a drug as "Any substance, solid, liquid or gas that changes the function or structure of the body in some way... a substance that causes changes in mental processes" WHO further observed that harmful effects of drugs were varied depending on the substance used, the amount consumed, the method of use, the general condition of the individual, the age of onset and the length of time the drug is abused. Califano Jnr (2002) observed that the youth were attracted to using drugs for immediate and short time excitement. The following predisposing factors were responsible for onset of drug abuse: adolescence, being a time of rapid physical and emotional change exposed the youth to peer pressure for which they did not have adequate skills to deal with or cope. Family members who abused drugs were also seen as contributing to youth abuse of drugs especially smoking tobacco.

Adolescence behaviour has been found to lead to the trying out of new experiences such as drug and sex, sometimes with dire consequence for the adolescents. One widely accepted definition of drugs states that drugs are compounds that, because of their chemical structure, change the functioning of biological systems (Levinthal, 2000). The biological systems include respiration, growth, excretion, locomotion and reproduction. The effects may be beneficial as in the case when drugs commonly referred to as medicines are used as prescribed by qualified physician. Some other drugs have been found to be capable of producing effects that are harmful to the user (Oloyede, 1996). The term drug abuse, applies only to instances in which people take drugs purely to change their moods, and in which they experience impaired behaviour or social functioning as a result of doing so (Wallace \& Fisher 2003).

When people consume consciousness-altering drugs on a regular basis, they often develop dependence, and come to need the drug and cannot function without it. According to Odejide, Ohaeri, Adelekan and Ihuesan (2005), psychoactive drug use is a common problem among adolescents especially for the socially acceptable drugs like alcohol and cigarettes. A survey of secondary school students in Ilorin, Kwara State in Nigeria reported that $12 \%$ were currently using alcohol (Abiodun, Adelekan, Ogunremi, Oni \&Obayan, 2005). In a study of out-of-school adolescents aged 11 to 20 in Jos, found a lifetime consumption of alcohol reported by $38.7 \%$ of the respondents (Obot, Ibagam, Ojiji\&Wai, 2001).

Majority of marijuana use starts during the adolescence stage especially so for the 'gateway' drugs, alcohol and cigarettes. Alcohol and cigarettes are described 'as gateway' because they are usually, the first drugs one encounters before graduating to hard drugs. Drug abuse by students often leads to sharp decline in their academic performance, increased reports of truancy and expulsion from school. It has also been known to lead to addiction and increased dependence on drugs without which normal life processes is disturbed. Drug addiction invariably leads to other vices such as stealing, violence and gambling.

Continued use of a drug over a prolonged period of time often leads to drug tolerance as well as physical and psychological problems. Tolerance is a physiological condition in which the body requires higher doses in order to experience the same effects. In some cases, tolerance for one drug increases tolerance for another; this is known as cross-tolerance (Baron \&Kalsher, 2008). Patterns of drug use may vary greatly around the world and overtime. In the United States, the use of many consciousness-altering drugs by young people dropped during the 1980's, but increased again during the 1990s (Baron \&Kalsher, 2008). The result of one survey indicated that teenagers' use of many drugs including, alcohol, cocaine, marijuana, and nicotine had increased substantially (Johnston, O’Malley \&Bochman, 1997).

\section{Methodology}

The study was conducted in Kakamega County, Kenya, and used the ex post facto research design because the study sought to establish the association between variables that had already occurred. The target population was form four students (28353), principals (323), school guiding and counselling teachers (323), parents/guardians, religious leaders, chiefs, NG-CDF managers and sub county directors of education (13). This study used a 
combination of purposive, systematic random and stratified proportionate sampling techniques to get the required samples of 697 respondents. The study used questionnaires, interview schedules and focus group discussions for primary data collection and document content analysis as secondary data collection tools. This study yielded both qualitative and quantitative data. The responses from interviews and focus group discussions were also captured and presented verbatim from respondents. Data were analysed using the Statistical Package for Social Science (SPSS) version 20. The statistics used were The Pearson Chi-square, Spearman Rank Correlation Coefficient and The stepwise Multiple Regression Analysis.

\section{Results and Discussion}

4.1 Social and economic conflicts affecting participation in secondary school education

This sub-section presents findings on the social and economic conflicts affecting students' participation in secondary school education in Kakamega County.

4.1.1 Threats to participation in secondary education

Students were asked to indicate what they consider the biggest problem or threat to their education. Their responses were as presented in Table 1.

Table 1: Threats to participation in secondary school education

\begin{tabular}{lcc}
\hline Threat & Frequency & Percentage \\
\hline Fees Balance & 335 & 59.82 \\
Poverty & 253 & 45.18 \\
Learning materials & 206 & 36.79 \\
Absenteeism & 201 & 35.89 \\
Peer pressure & 201 & 35.89 \\
Home environment & 199 & 35.54 \\
Boy Girl Relationship & 195 & 34.82 \\
Drugs & 180 & 32.14 \\
Poor Performance & 322 & 57.5 \\
School facilities & 154 & 27.5 \\
Insecurity & 144 & 25.72 \\
Labour & 122 & 21.79 \\
Indiscipline & 104 & 18.57 \\
Stress & 84 & 15 \\
Disturbance by bodaboda men & 64 & 11.43 \\
Household chores & 61 & 10.89 \\
Lack of family support & 45 & 8.04 \\
\hline
\end{tabular}

(Source: Field Data, 2018).

Data in Table 1 shows that 335 students $(59.82 \%)$ indicated that fees balances were threat to their education, 253 students $(45.18 \%)$ indicated that poverty was the greatest threat to their education. Other significant threats identified by students included lack of learning materials (36.79\%), absenteeism $(35.89 \%)$, peer pressure $(35.89 \%)$, unconducive home environment (35.54\%), Boy Girl Relationship (34.82\%), teachers bullying (34.11\%), family issues (33.57\%), school punishment (33.04\%), drugs (32.14\%), insecurity (25.72) among others. The threats to student education were classified according to school factors, home factors, environment and community factors. The threat of sexual molestation by bodaboda riders was cited especially by female students in day schools. Family issues such as separation, parent pressure, lack of support from (extended) family, household chores, poverty and fees balances were also cited by respondents.

4.1.2 Prompt payment of School fees

The sampled students were asked to indicate whether their school fees and other school levies were paid on time, and whether in their opinion they believed the family income was adequate. The findings were as presented in Figure 1 . 


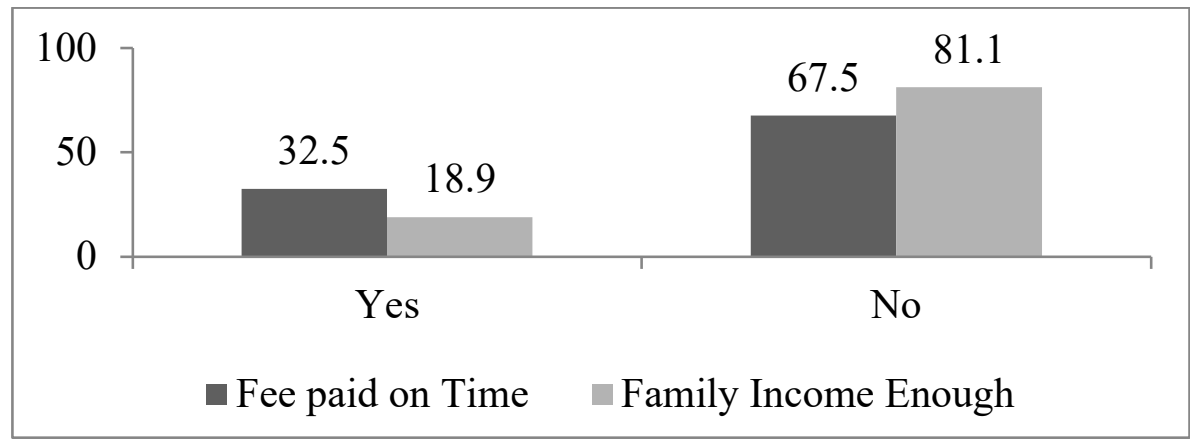

Figure 1: Payment of fees and Family Income (Source: Field data, 2018).

The findings presented in Figure 1 showed that $32.5 \%$ of the students indicated that fees were paid on time while $67.5 \%$ reported that their fees were not paid on time. It was further revealed that $18.9 \%$ of the students felt the family income was enough to support their needs including education as compared to $81.1 \%$ of the sampled students who indicated that their family income was not sufficient to support their school fees and other family requirements. This indicates that the level of poverty was significantly high and would likely affect participation in secondary education in Kakamega County.

\subsubsection{Child labour}

The sampled student respondents were asked to indicate whether they have had to work to raise money for school fees and other school needs. The responses were as shown in Figure 2.

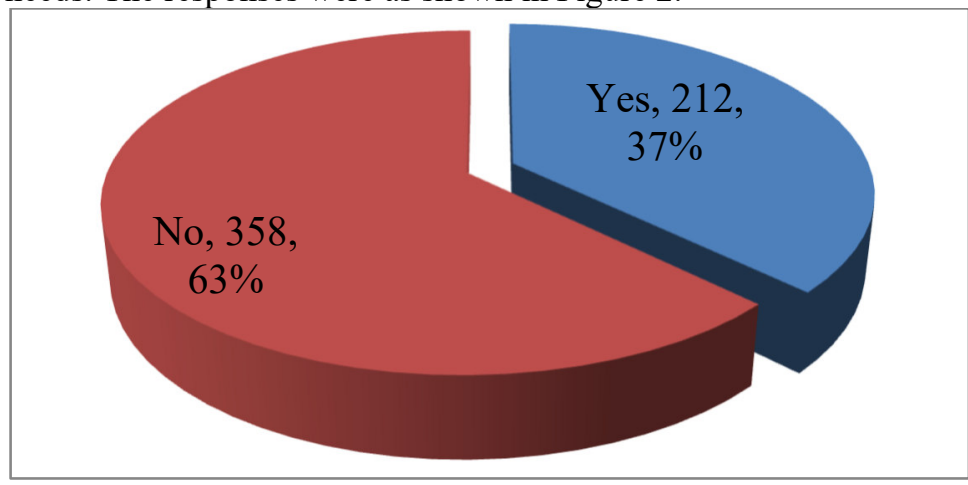

Figure 2: Child Labour among students. (Source: Field data, 2018).

The results in Figure 2 show that 212 students (37\%) indicated that they have had to work so as to raise money for school fees and other school needs while 358 students (63\%) said they were not required to work to raise money for school needs. The percentage of students who engaged in some form of employment to earn money which they used to pay for education needs was significantly high at $37 \%$. The implication was that the students used some of the time they were to be in school to engage in work thereby negatively affecting participation through absenteeism and outright drop out. The balance between academics and work was fairly delicate.

\subsubsection{Type of work by students}

The students who indicated that they worked to raise money to finance their education requirements were asked to state the type of work they engaged in. Their responses were as shown in Figure 3.

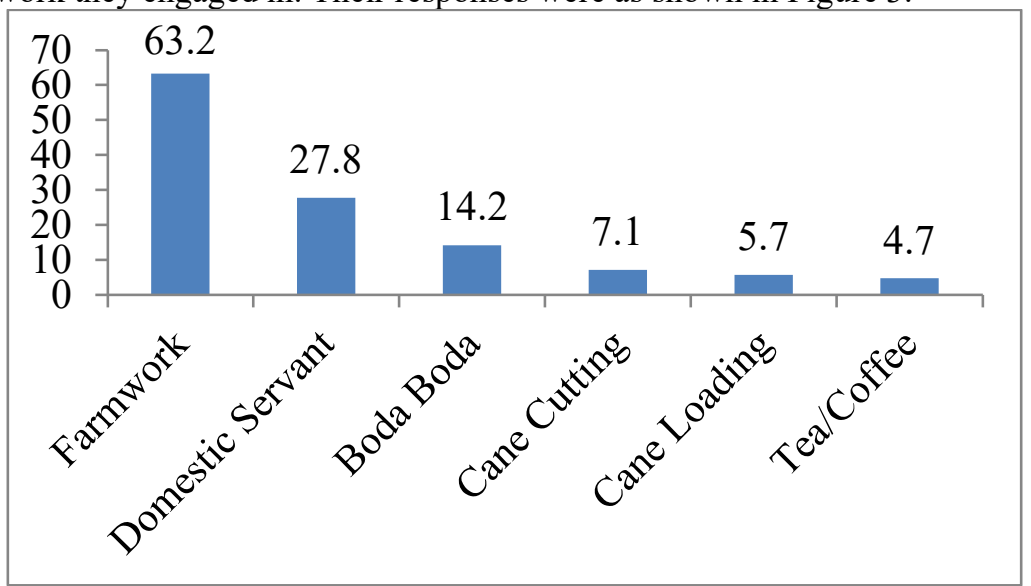

Figure 3: Type of work by students. (Source: Field data, 2018). 
Data in Figure 3, shows that $63.2 \%$ of the students who indicated that they worked were engaged as farm workers, while $27.8 \%$ were hired as domestic servants. Motor bike BodaBoda riding engaged 14.2\%, cane cutting $7.1 \%$, Cane loading $5.7 \%$ while $4.7 \%$ were employed in tea/coffee picking. Overall, $80.7 \%$ were engaged in agricultural sector whereas $27.8 \%$ were domestic servants and $14.2 \%$ were in transport industry. Cane cutting and loading was found to be prevalent in Mumias East and Kakamega North Sub counties. This was largely due to the presence of Mumias Sugar Factory in Mumias East, West Kenya Sugar and Butali Sugar factories in Kakamega North. These factories stimulated sugar farming to become the dominant activity and economic mainstay in the two sub counties and were the main source of petty employment. Tea picking as an activity was reported mainly in Kakamega East while BodaBoda riding, as an economic activity, was reported in all the sub counties.

4.1.4 Availability of learning materials

The sampled students were asked to indicate whether, in their opinion there were essential school items that they did not have. They were also asked to indicate the essential items that they did not have. The responses were as presented in Figure 4.

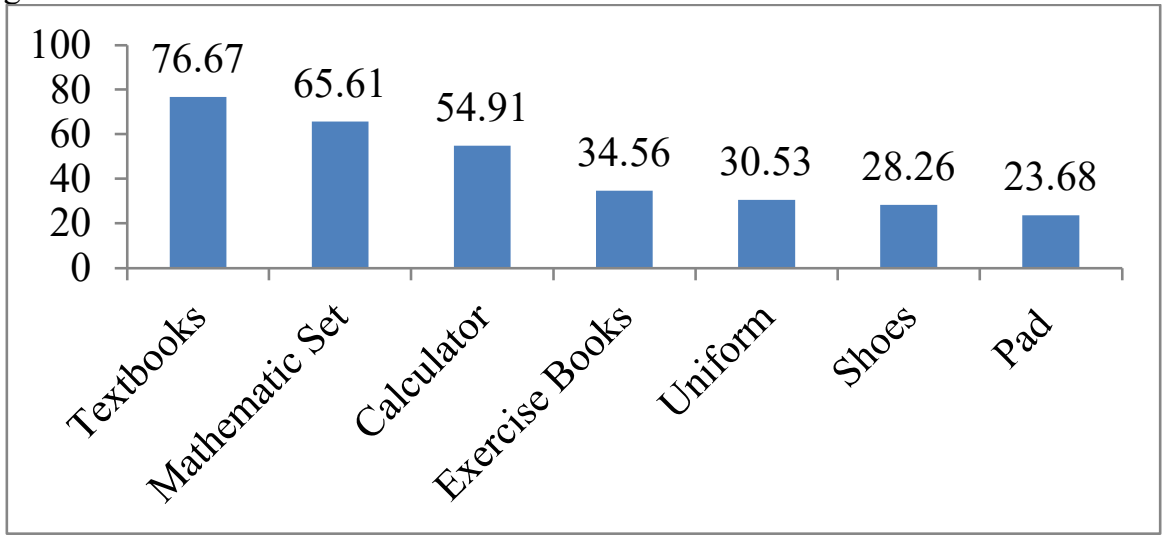

Figure 4: Lack of Learning Materials. (Source: Field data, 2018).

The data in Figure 4 shows that a majority of the students $(81.4 \%)$ reported that they did not have some essential items that were required in school as compared to $18.6 \%$, who reported that they had sufficient and adequate items needed in school. Students who indicated that they lacked some essential items were further asked to name the essential items they did not have. The responses were as presented in Figure 4 . It was found that majority $(76.67 \%)$ of sampled students indicated they lacked textbooks. These included set books, classroom text books, mathematical table as well as revision books. It was also found that $65.61 \%$ of the students indicated they did not have mathematical/geometrical set, while $54.91 \%$ indicated they did not have calculator, $34.56 \%$ said they did not have exercise books, $30.53 \%$ did not have school uniform and games kit, $28.26 \%$ lacked shoes and $23.68 \%$ of the sampled girls lacked sanitary pads. When the items were categorized as direct and indirect needs, it was found that that direct costs of education in terms of textbooks, Mathematical instruments and exercise books were the most crucial.

Hidden costs of education were also significant. These were uniforms including shoes. Many girls also reported that they did not have sanitary towels, the percentage of all students was $23.68 \%$. Looked at from a global sample perspective, the percentage tended to downplay the gravity of the problem. When actual frequencies were checked against the female child respondents, it was found that 153 girls $(60.38 \%)$ out of 255 indicated they did not have sanitary pads. This posed a great challenge to the girls and was largely responsible for a high levels of absenteeism, thereby impacting on their participation in secondary school education. These findings concur with the findings by Ngwacho (2011), Kingori (2015), EFA (1990) and Townsend (1979) on the effects of the hidden costs of education on participation. The findings also reflect the 1995 United Nations definition of poverty as a condition characterised by severe deprivation of basic human needs, including food, safe drinking water, sanitation facilities, health, shelter, education and information (UN, 2016). Kakamega County was found to have social and economic challenges as reported by students that impacted negatively on their participation in secondary school education.

\subsection{Findings from Guidance and Counseling Teachers}

Guidance and counselling teachers were asked about the social and economic conflicts that were prevalent in Kakamega county and were likely to affect students' participation in secondary school education. These included orphanhood, family status, teenage pregnancy, HIV and AIDS, (repugnant and disruptive) cultural activities, child labour and poverty. These were further categorized as social and economic. The responses by Guidance and Counselling teachers were as presented in the following sections. 


\subsubsection{Prevalence of social conflicts}

The social conflicts as used in this study included orphan hood, broken family units, teenage pregnancy and HIV and AIDS

\subsubsection{Orphan hood, Broken Family Units and HIV and AIDS}

The guidance and counselling teachers were asked to rank the variables of orphan hood, broken family units and HIV and AIDS in order of severity as they affected participation in their schools. The results were as shown in Table 2.

Table 2: Guidance and Counselling teachers ranking of challenges

\begin{tabular}{|l|c|c|c|c|c|c|}
\hline Severity & \multicolumn{2}{|c|}{ Orphan Hood } & \multicolumn{2}{c|}{ Broken Family } & \multicolumn{2}{c|}{ HIV and AIDS } \\
\hline & $\mathrm{f}$ & $\%$ & $\mathrm{f}$ & $\%$ & $\mathrm{f}$ & $\%$ \\
\hline 1 & 7 & 31.8 & 15 & 68.2 & 6 & 27.3 \\
\hline 2 & 15 & 68.2 & 5 & 22.7 & 3 & 13.6 \\
\hline 3 & & & 1 & 4.5 & 5 & 22.7 \\
\hline 4 & & & 1 & 4.5 & 2 & 9.1 \\
\hline 5 & & & & & 6 & 27.3 \\
\hline 6 & & & & & 6 & 27.3 \\
\hline
\end{tabular}

(Source: Field data, 2018).

From Table 2, Orphan hood was ranked as the most severe by seven (7) guidance and counselling teachers $(31.8 \%)$. Fifteen (15) guidance and counselling teachers $(68.2 \%)$ ranked orphanhood as the second most severe challenge. The results further revealed that fifteen (15) guidance and counselling teachers $(68.2 \%)$ ranked broken family as most severe, while five (5) teachers $(22.7 \%)$ ranked broken family as the second most severe. One teacher (4.5\%) ranked broken family as moderately severe while one teacher $(4.5 \%)$ did not think broken family was a challenge. For HIV and AIDS, six (6) guidance and counselling teachers (27.3\%) ranked it as most severe, three (3) teachers $(13.6 \%)$ ranked it as second most severe, five teachers $(22.7 \%)$ ranked it as third in severity, two (2) teachers $(9.1 \%)$ ranked it as fourth, six teachers $(27.3 \%)$ ranked it as fifth while six $(27.3 \%)$ ranked HIV and AIDS as the least severe. From the distribution of ranking, it was evident that guidance and counselling teachers did not think HIV and AIDS was a major challenge to students' participation in secondary school education in Kakamega county. This was probably due to improved palliative care and management of HIV and AIDS thereby reducing the effect of the scourge on society in general and the youth in particular.

4.2.1.2 Teenage pregnancy, Teenage marriage and Boy Girl Relationship

The guidance and counselling teachers were asked to rank the severity of teenage pregnancy, teenage marriage and boy girl relationship in their schools. The results were as shown in Table 3.

Table 3: Teenage pregnancy, teenage marriage and boy-girl relationships

\begin{tabular}{|l|c|c|c|c|c|c|}
\hline \multicolumn{1}{c|}{ Rank } & \multicolumn{2}{c|}{ Teenage Pregnancy } & \multicolumn{2}{c|}{ Teenage Marriages } & \multicolumn{2}{c|}{ Boy Girl Relationship } \\
\hline & $\mathrm{f}$ & $\%$ & $\mathrm{f}$ & $\%$ & $\mathrm{f}$ & $\%$ \\
\hline 1 & 9 & 40.9 & & & 8 & 36.4 \\
\hline 2 & 5 & 22.7 & 4 & 18.2 & 11 & 50.0 \\
\hline 3 & 8 & 36.4 & 16 & 72.7 & 3 & 13.6 \\
\hline 4 & & & 2 & 9.1 & & \\
\hline
\end{tabular}

(Source: Field data, 2018)

The results in Table 3 show that nine (9) guidance and counselling teachers (40.9\%) ranked teenage pregnancy as most severe, five (5) teachers $(22.7 \%)$ ranked it as second in severity while eight (8) teachers $(36.4 \%)$ ranked as third most severe in their school. The results also show that four (4) guidance and counselling teachers (18.2\%) ranked teenage marriages as second in severity, sixteen (16) guidance and counselling teachers $(72.7 \%)$ ranked teenage marriage as the third most severe challenge while two (2) teachers $(9.1 \%)$ ranked it as third and least terms of severity. Boy girl relationship was ranked by eight (8) guidance and counselling teachers (36.4\%) as most severe challenge in their school, eleven (11) teachers (50\%) ranked it as second and three teachers ranked boy girl relationship at second place and three (3) teachers (13.6\%) ranked it as third most severe. These three challenges are however, intertwined. Boy - girl relationship was found to be the most severe challenge in school perpetrated by either members within the school or from outside the school. These relationships were found to take place between students in neighbouring schools as in the case of Kibabii Boys School and Cardinal Otunga Girls, (Mbuthia, The Standard: 26 ${ }^{\text {th }}$ March 2018).

4.1.2.3 Cultural activities

The guidance and counselling teachers were asked to rank the severity of cultural activities of funerals and initiation ceremonies on the participation in education in their schools. Their responses were as presented in Table 4. 
Table 4: Cultural activities

\begin{tabular}{|l|c|c|c|c|}
\hline Rank & \multicolumn{2}{|c|}{ Funerals } & \multicolumn{2}{c|}{ Initiations } \\
\hline & $\mathrm{f}$ & $\%$ & $\mathrm{f}$ & $\%$ \\
\hline 1 & 3 & 13.6 & 1 & 4.5 \\
\hline 2 & 10 & 45.5 & 7 & 31.8 \\
\hline 3 & 6 & 27.3 & 3 & 13.6 \\
\hline 4 & 2 & 9.1 & 4 & 18.2 \\
\hline 5 & 1 & 4.5 & 3 & 13.6 \\
\hline 6 & & & 4 & 18.2 \\
\hline
\end{tabular}

(Source: Field data, 2018)

The results in Table 4 show that three (3) guidance and counselling teachers (13.6\%) ranked funeral as most severe, ten (10) teachers (45.5\%) ranked it as second most severe, six (6) teachers $(27.3 \%)$ teachers ranked it as third most severe. On the other hand, two (2) teachers (9.1\%) ranked it as fourth while one (1) teacher (4.5\%) as least severe. It was also observed that one (1) teacher (4.5\%) ranked initiations as most severe, seven (7) teachers $(31.8 \%)$ ranked initiations as second most severe, three (3) teachers $(13.6 \%)$ ranked it as third most severe. Four (4) teachers $(18.2 \%)$ ranked it as fourth, three (3) teachers (13.6\%) ranked it fifth while four (4) teachers $(18.2 \%)$ ranked it sixth and least in severity.

4.1.2.4 Ranking of social conflicts

The study further computed the overall ranking of social conflicts as ranked by the guidance and counselling teachers. The conflict with the least severity rank mean was ranked top while the conflict with a higher severity rank mean was ranked at the bottom. The results are as shown Table 5.

Table 5: Ranking of social conflict variables

\begin{tabular}{lcc}
\hline Social Conflict & Rank Value & Mean Rank \\
\hline Broken Family Units & 1.45 & 1 \\
Orphan Hood & 1.68 & 2 \\
Boy Girl Relationship & 1.77 & 3 \\
Teenage Pregnancy & 1.95 & 4 \\
Funerals & 2.45 & 5 \\
Teenage Marriages & 2.90 & 6 \\
Initiation ceremonies & 3.52 & 7 \\
HIV and AIDS & 3.95 & 8 \\
\hline
\end{tabular}

(Source: Field data, 2018).

Data in Table 5 shows the overall mean rankings of the social conflicts affecting students' participation in secondary schools in Kakamega County as reported by guidance and counselling teachers from the sampled schools. The results indicate that broken family units with a mean rank of 1.45 was the most severe social conflict, followed by orphan hood at 1.68 , boy girl relationship at position three with a mean rank of 1.77 , teenage marriage with a mean rank of 2.9, initiation ceremonies with mean rank of 3.52 and HIV and AIDS with a mean rank of 3.95 was found to have the least effect on students' participation in secondary school education in Kakamega county.

4.1.3 Economic conflicts

The economic conflicts as used in this study included poverty and child labour. The findings are as presented below.

4.1.3.1 Poverty

The guidance and counselling teachers were asked to rank the severity of poverty as it affected students' participation in their school. The results are as shown in Table 6.

Table 6: Poverty and participation

\begin{tabular}{lcc}
\hline Rank & \multicolumn{3}{c}{ Poverty } \\
& f & $\%$ \\
\hline 1 & 17 & 77.3 \\
2 & 3 & 13.6 \\
3 & 2 & 9.1 \\
\hline
\end{tabular}

(Source: Field Data, 2018).

The results in Table 6 show that seventeen (17) guidance and counselling teachers (77.3\%) ranked poverty as most severe economic conflict influencing participation in secondary school education, while three (3) teachers $(13.6 \%)$ ranked it as second most severe while two (2) teachers $(9.1 \%)$ ranked it as third.

4.1.3.2 Child Labour

The guidance and counselling teachers were asked to rank the severity of child labour as it influenced students' 
participation in their school. The results were as shown in Table 7.

Table 7: Child labour and participation

\begin{tabular}{|l|c|c|}
\hline Rank & \multicolumn{2}{|c|}{ Child Labour } \\
\hline & $\mathrm{f}$ & $\%$ \\
\hline 1 & 11 & 50.0 \\
\hline 2 & 2 & 9.1 \\
\hline 3 & 3 & 13.6 \\
\hline 4 & 4 & 18.2 \\
\hline 5 & 1 & 4.5 \\
\hline 6 & 1 & 4.5 \\
\hline
\end{tabular}

(Source: Field data, 2018)

As shown in Table 7, eleven (11) guidance and counselling teachers (50\%) ranked child labour as the most severe economic conflict, two (2) teachers $(9.1 \%)$ ranked child labour as the second most severe, three (3) teachers $(13.6 \%)$ ranked it as third, four (4) teachers $(18.2 \%)$ ranked it fourth and one (1) teacher $(4.5 \%)$ ranked child labour fifth and sixth respectively.

\subsubsection{Type of labour}

The sampled guiding and counselling teachers were asked to rank the order of severity of child labour such as bodaboda, domestic servants, farm work, cane cutting, cane loading, and family chores. The results were as presented in Table 8.

Table 8: Type of Labour

\begin{tabular}{|c|c|c|c|c|c|c|c|c|c|c|c|c|}
\hline \multirow[t]{2}{*}{ Rank } & \multicolumn{2}{|c|}{ BodaBoda } & \multicolumn{2}{|c|}{$\begin{array}{c}\text { Domestic } \\
\text { Servant }\end{array}$} & \multicolumn{2}{|c|}{ Farm work } & \multicolumn{2}{|c|}{ Cane cutting } & \multicolumn{2}{|c|}{$\begin{array}{c}\text { Cane } \\
\text { Loading }\end{array}$} & \multicolumn{2}{|c|}{$\begin{array}{c}\text { Family } \\
\text { Chore }\end{array}$} \\
\hline & f & $\%$ & $\mathrm{f}$ & $\%$ & f & $\%$ & $\mathrm{f}$ & $\%$ & $\mathrm{f}$ & $\%$ & f & $\%$ \\
\hline 1 & 3 & 13.6 & 3 & 13.6 & & & & & & & 4 & 18.2 \\
\hline 2 & 5 & 22.7 & 1 & 4.5 & 6 & 27.3 & 6 & 27.3 & 8 & 33.3 & 4 & 18.2 \\
\hline 3 & 12 & 54.5 & 6 & 27.3 & 11 & 50.0 & 8 & 36.4 & 1 & 4.8 & 8 & 36.4 \\
\hline 4 & & & 10 & 45.5 & 3 & 13.6 & 1 & 4.5 & 7 & 28.6 & 5 & 22.7 \\
\hline 5 & 2 & 9.1 & 2 & 9.1 & 2 & 9.1 & 8 & 31.8 & 7 & 28.6 & & \\
\hline 6 & & & & & & & & & 1 & 4.8 & 1 & 4.5 \\
\hline Mean & & 2.6818 & & 3.3182 & & 3.0455 & & 3.4091 & & 3.6667 & & 2.8182 \\
\hline Rank & & & & & & & & & & & & \\
\hline Position & & 1 & & 4 & & 3 & & 5 & & 6 & & 2 \\
\hline
\end{tabular}

From Table 8, three (3) guidance and counselling teachers (13.6\%) ranked bodaboda as the first choice of work for students, while five (5) teachers (22.7\%) ranked it as second. Twelve (12) teachers $(54.5 \%)$ ranked bodaboda at third position in terms of the most common form of labour secondary school students are likely to engage in. The results also show that three (3) teachers (13.6\%) ranked domestic servant as the most preferred choice for students while ten (10) guidance and counselling teachers (45.5\%) ranked it as a fourth alternative. None of the sampled guidance and counselling teacher's ranked farm work, cane cutting and cane loading as a preferred choice for students. However, 27.3\% ranked farm work and cane cutting as second alternative for students as compared to $33.3 \%$ of the teachers who indicated cane loading was a preferred option by students.

When the mean rank was computed for the preferred jobs, it was found that the guidance and counselling teachers ranked bodaboda as the most attractive form of labour to students with a mean rank of 2.6818, followed by family chores at 2.8182 , farm work at 3.0455 , domestic servant at 3.3182 cane cutting at 3.4091 and cane loading at a mean rank of 3.6667 was the least preferred.

4.1.3.4 Prevalence of social and economic conflicts

This study computed the mean rankings by guidance and counselling teachers of the listed social and economic challenges in Kakamega County. The mean rankings were presented in Table 9. 
Table 9: Mean ranking of social and economic conflicts

\begin{tabular}{lcc}
\hline Social conflict & Mean Rank & Rank \\
\hline Poverty & 1.32 & 1 \\
Broken Family Units & 1.45 & 2 \\
Orphan Hood & 1.68 & 3 \\
Boy Girl Relationship & 1.77 & 4 \\
Teenage Pregnancy & 1.95 & 5 \\
Child Labour & 2.32 & 6 \\
Funerals & 2.45 & 7 \\
Teenage Marriages & 2.90 & 8 \\
Initiation & 3.52 & 9 \\
HIV and AIDS & 3.95 & 10 \\
\hline
\end{tabular}

(Source: Field Data, 2018).

From the data in Table 9, guidance and counselling teachers ranked poverty as the most prevalent challenge to participation in secondary school education in Kakamega County with a mean rank of 1.32 . In second position was broken or dysfunctional family units which had a mean rank of 1.45 while orphanhood was third with a mean rank of 1.68. On the other hand HIV and AIDS was ranked as having the least influence on participation in secondary school education by guidance and counselling teachers with a mean rank of 3.95 .

\subsection{Stepwise multiple regression analysis}

This study further carried out a stepwise multiple linear regression analysis of the variables to determine the contribution of social and economic conflicts to students' participation in secondary school education in Kakamega County. The results in this section are presented according to student participation.

4.2.1 Social and economic conflicts and academic performance

Data on social and economic challenges were entered against academic performance and the results presented in Table 10.

Table 10: Social and economic conflicts and performance

\begin{tabular}{cccccccc}
\hline Model & $\mathrm{R}^{2}$ & Adjusted R & Std. Error of the Estimate & $\begin{array}{l}\text { R Square } \\
\text { Change }\end{array}$ & $\begin{array}{c}\text { Statistics } \\
\text { F Change }\end{array}$ & \multicolumn{2}{c}{$\begin{array}{c}\text { Sig. F } \\
\text { Change }\end{array}$} \\
\hline 1 & .579 & .569 & .98392 & .579 & 57.821 & 1,42 & .000 \\
2 & .631 & .613 & .93301 & .051 & 5.709 & 1,41 & .022
\end{tabular}

a. Predictors: (Constant), Poverty

b. Predictors: (Constant), Poverty, Boy Girl Relationship (Source: Field data, 2018).

The results in Table 10 revealed social and economic conflicts affected academic performance up to $63.1 \%$ $\left(\mathrm{R}^{2}=0.631\right)$. Based on the above values it shows that poverty contributes $56.9 \%\left(\mathrm{R}^{2}=0.569\right)$ in explaining variance in academic performance, while the contribution of boy girl relationship is $5.1 \%\left(\mathrm{R}^{2}=0.051\right)$. Therefore, poverty has the highest contribution to academic performance.

4.2.2 Social and economic conflicts and absenteeism

Data on social and economic conflicts were regressed against absenteeism and the results presented in Table 11. Table 11: Social and economic conflicts and absenteeism

\begin{tabular}{|c|c|c|c|c|c|c|c|}
\hline \multirow[t]{2}{*}{ Model } & \multirow[t]{2}{*}{$\mathrm{R}^{2}$} & \multirow[t]{2}{*}{ Adjusted $\mathrm{R}^{2}$} & \multirow[t]{2}{*}{ Std. Error of the Estimate } & \multicolumn{4}{|c|}{ Change Statistics } \\
\hline & & & & R Square Change & F Change & df & Sig. F Change \\
\hline 1 & .208 & .189 & 1.11358 & .208 & 11.003 & 1,42 & .002 \\
\hline
\end{tabular}

a. Predictors: (Constant), Teenage Marriages

(Source: Field data, 2018).

The results in Table 11 revealed social and economic conflicts explained absenteeism up to $20.8 \%\left(\mathrm{R}^{2}=0.208\right)$. Based on the above values it shows that teenage marriages contribute $20.8 \%$ in explaining variance in absenteeism in Kakamega County.

4.2.3 Social and economic conflicts and transfer

Data on social and economic conflicts were regressed against students' transfer across schools and the results presented in Table 12. 
Table 12: Social and economic conflicts and transfer

\begin{tabular}{cccccccc}
\hline Model & $\mathrm{R}^{2}$ & Adjusted $\mathrm{R}^{2}$ & \multicolumn{2}{c}{ Std. Error of the Estimate } & \multicolumn{4}{c}{ Change Statistics } \\
& & & & R Square Change & F Change & df & Sig. F Change \\
\hline 1 & .100 & .078 & 1.02646 & .100 & 4.657 & 1,42 & .037 \\
2 & .212 & .173 & .97232 & .112 & 5.807 & 1,42 & .021 \\
\hline
\end{tabular}

a. Predictors: (Constant), Poverty

b. Predictors: (Constant), Poverty, Fee balances

(Source: Field data, 2018).

The results in Table 12 revealed social and economic conflicts affected transfer of students to other schools up to $21.2 \%\left(R^{2}=0.212\right)$. Based on the above values it shows that poverty contributes $10.0 \%\left(R^{2}=0.10\right)$ in explaining variance in transfer of students to other schools, while the contribution of fee balances is $11.2 \%$ $\left(\mathrm{R}^{2}=0.112\right)$. Therefore, fee balances had the highest contribution to transfers to other schools in Kakamega County. 4.2.4 Social and economic conflicts and drop-out rate

Data on social and economic conflicts were regressed against drop-out rates and the results presented in Table 13.

Table 13: Social and economic conflicts and drop-out rates

\begin{tabular}{cccccccc}
\hline Model & $\mathrm{R}^{2}$ & Adjusted $\mathrm{R}^{2}$ & Std. Error of the Estimate & \multicolumn{4}{c}{ Change Statistics } \\
& & & & R Square Change & F Change & df1 & Sig. F Change \\
\hline 1 & .170 & .150 & 1.12866 & .170 & 8.579 & 1,42 & .005
\end{tabular}

a. Predictors: (Constant), Orphan hood. (Source: Field data, 2018).

The results in Table 13 revealed social and economic conflicts explained dropout rate up to $17.0 \%\left(\mathrm{R}^{2}=0.170\right)$. Based on the above values it was found that orphan hood contributed $20.8 \%$ in explaining variation in dropout rates in Kakamega County

4.2.5 Social and economic conflicts and fees balances

Data on social and economic conflicts were regressed against fee balances and the results were as presented in Table 15.

Table 15: Social and economic conflicts and fee balances

\begin{tabular}{ccccccc}
\hline R Square & $\begin{array}{c}\text { Adjusted R } \\
\text { Square }\end{array}$ & $\begin{array}{c}\text { Std. Error of the } \\
\text { Estimate }\end{array}$ & $\begin{array}{c}\text { Change Statistics } \\
\text { R Square } \\
\text { Change }\end{array}$ & $\begin{array}{c}\text { F Change df1, df2 } \\
\text { Sig. F Change }\end{array}$ \\
\hline .146 & .125 & .94791 & .146 & 7.171 & 1,42 & .011 \\
.249 & .212 & .89959 & .103 & 5.634 & 1,41 & .022 \\
.338 & .289 & .85486 & .089 & 5.403 & 1,40 & .025 \\
\hline
\end{tabular}

a. Predictors: (Constant), Poverty

b. Predictors: (Constant), Poverty, Broken Family Units

c. Predictors: (Constant), Poverty, Broken Family Units, Orphan hood

(Source: Field data, 2018).

The results in Table 15 revealed social and economic conflicts affected fees balances up to $33.8 \%\left(\mathrm{R}^{2}=0.338\right)$. Based on the above values it showed that poverty contributed $14.6 \%\left(\mathrm{R}^{2}=0.146\right)$ in explaining variation in school fee balances while the contribution of broken family unit was $10.3 \%\left(\mathrm{R}^{2}=0.103\right)$ and lastly orphan hood contributed $8.9 \%$ change in fee balances as indicated by $\mathrm{R}$ square of 0.089 . Therefore, poverty was found to have the highest contribution to fee balances amongst social and economic conflicts in Kakamega County.

\section{Conclusion}

The findings indicated that secondary students in Kakamega County faced significant social and economic conflicts that compromised their participation in secondary school education. The study also found the conflicts were prevalent. Therefore, there was a significant relationship between socio-economic conflicts and students participation in secondary schools in the county. The conflicts negatively affected students' participation in secondary school education in the study area.

\section{Recommendation}

This study therefore recommends that the government and other stakeholders in education should come up with strategies to address the social and economic conflicts that negatively impact on students' participation in secondary school education in Kakamega county.

\section{References}

Abebe, T. (2009). Orphanhood, Poverty and the Care Dilemma: Review of Global Policy Trends. Social work and Society. International Online Journal. 7 (1). 
Abiodun, O. A., Adelekan, M. L., Ogunremi., Oni., \& Obayan. (1994). Pattern of substance abuse within secondary school student in Ilorin, Northern Nigeria. West African Journal of Medicine, 13, 91-7.

Barasa, S. F., Wamue-Ngare, D. \& Wanjama, L. (2013). Experience of school-related gender-based violence by pupils and the culture of silence: A case of primary Schools in Kasarani District, Nairobi County, Kenya. International Journal of Education and Research. 1 (3), March 2013.

Bergeson, T. (2006): Race, poverty, and academic achievement. http://www.doh.wa.gov/SBOH/ESS/documents/Race\&Poverty.pdf

Brock, C. \& Cammish, N. K. (1997). Factors Affecting Female Participation in Education in Seven Developing Countries. Education Research Paper No. 9. London, UK: DFID.

Buvinic, M., Das Gupta, M., Casabonne, U. \& Verwimp, P. (2013). Violent Conflict and Gender Inequality: An Overview. Policy Research Working Paper 6371. The World Bank Development Economics Vice Presidency Partnerships, Capacity Building Unit February 2013.

Califano, J. Jnr. (2002). Marijuana is a Gateway Drug. in Espejo, R.(Ed).(2002). Drug Abuse. San Diego, CA: Greenhaven Press.

Chege, F. (2007). Education and empowerment of girls against gender-based violence. In Journal of Educational Cooperation in Education.Vol.10, No. 1, 2007, pp.53-70. Hiroshima University.

Chege, F. and Mati, F. (1997). Researching Sexual Harassment in Educational Institutions: A case study of Weupe Primary School, Kenya. Report Presented at a Cross-country Workshop on Methodologies for Studying Sexual Harassment in Educational Institutions. Entebbe, Uganda.

Chen, Q. (2009). Family background, ability and students' achievement in Rural China: Identifying the effects of unobservable ability using feminine-generated instruments. http.//repository.upenn.edu/gansu papers/26

Chireshe, R. (2010). The impact of poverty on women's psychosocial well-being: Narratives from Zimbabwean migrant women in South Africa. Journal of Psychology in Africa, 20(2), 193-198.

Considine, G. \& Zappala, G. (2002). The influence of social and economic disadvantage in the academic performance of school students in Australia. Journal of Sociology, 38(2):129-148. June 2002

Danesty, A. H. \& Okediran, A. (2002). Etiological factors and effect of street working behaviour among Nigeria youth. Journal of Social Problem, School of Art and Social Science F.C.E. (special) Oyo, 2(1)..

Dayioglu, M. \& Turut-Asik, S. (2004). Gender Differences in Academic Performance in a Large Public University in Turkey. Middle East Technical University: Economic Research Centre Working Paper.

Farooq, M.S., Chaudhry, A.H., Shafiq, M. \& Berhanu, G. (2011). Factors affecting students' quality of academic performance: A case of Secondary School level. Journal of Quality and Technology Management, 7(2), 1-14.

Ganga, E. \& Chinyoka, K. (2010). Psychological disorders caused by poverty among orphans and vulnerable children in child headed households in Zimbabwe. Journal of Sustainable Development in Africa, 12(4), 186198.

Geremew, M. A., Dhufera, A. G. (2015). Factors that Influence Students Academic Performance: A Case of Rift Valley University, Jimma, Ethiopia. Journal of Education and Practice, 6(22), 55-63.

Johnston, L.D., O'Malley, P. M. \& Bachman, J. G. (1998). National Survey Results on Drug Use from the Monitoring The Future Study, 1975-1997 Volume I: Secondary School Students. Maryland: The University of Michigan Institute for Social Research National Institute on Drug Abuse.

Kathleen, B. R. \& Hilary A. R. (2002). Risk and Resiliency Factors among Adolescents Who Experience Marital Transitions. Journal of Marriage and Family, 64, 1024-1037.

Kent, G. (2006). Children as victims of structural violence. Societies Without Borders, 1, 53-67.

King'ori, J.N. (2015). Influence of Hidden Costs of Education on Students' Participation in Public Secondary Schools in Kikuyu Sub County, Kenya. University of Nairobi: Unpublished Med. (Educational Planning) Thesis.

Kuria, M.W. (1996). Drug abuse in urban as compared to rural secondary school students. East Africa Medical Journal, 73(5).

Levinthal, C. F. (1999). Drug Behaviour and Modern Society. Boston, MA: Allyn \& Bacon.

Manjoo, R. (2011). Report of the Special Rapporteur on Violence Against Women, its Causes and Consequences,

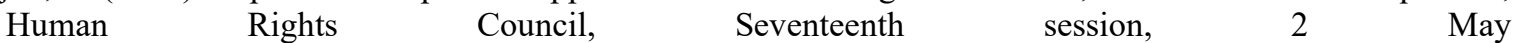
http://www.peacewomen.org/assets/file/Resources/UN/wps_reportofthespecialrapporteuronviolenceagains twomenitscausesandconsequences_un_may2011.pdf

Manwa, L., Ndamba, G.T. \& Manwa, L. (2010). A gendered dress code and how it influences the choice of dress by women in Zimbabwe. Journal of African Studies and Development, 2(6), 144-149.

Mayer, S.E. (2002). The Influence of Parental Income on Children's Outcomes. Report to the New Zealand Ministry of Social Development. http:// www.msd.govt.nz/about-msd-and-our-work/publicationsresources/research/influence-parental-income/index.html

Ngwacho, G.A. (2011). The Hidden Costs of Free Primary Education and their Implications on enrolment in Kisii central District, Kenya. Nairobi: Kenyatta University, Unpublished M.Ed. Thesis (Education Administration). 
Obot, I. S., Ibanga, A. J., Ojiji O. O. \& Wai, P. (2001). Drug and alcohol consumption by out of school Nigerian adolescents. African Journal of Drug and Alcohol Studies, 98-109.

Saferworld. (2014). Gender and Conflict Early Warning: Results of a literature review on integrating gender perspectives into conflict early warning systems. Briefing Note. Saferworld. http://www.saferworld.org.uk/downloads/pubdocs/gender-and-conflict-early-warning.pdf

Sclafani, S. (2010). Teacher Compensation around the Globe. Phi Delta Kappan, 91(8), 38 - 43 May, 2010.

Sentamu, N.P. (2003). School's influence of learning: A case of upper primary schools in Kampala \& Wakiso Districts.

Shittu, M.R. (2004). Socio-economic determinants of academic performance of secondary school students in Nigeria. University of Ilorin: Unpublished B. Ed project.

Simatwa, E.M.W., Odhong, S.O., Juma, S.L.A. \& Choka, G.M. (2014). Substance Abuse among Public Secondary School Students: Prevalence, Strategies and Challenges for Public Secondary School Managers in Kenya: A Case Study of Kisumu East Sub County. Educational Research, 5(8), 315-330.

Sisule, T.P. (2001). Poverty in the Eyes of Poor Kenyans: An Insight into the Poverty Reduction Strategy Paper (PRSP) Process. Tegemeo Institute, Egerton University.

Spooner, C. \& Hetherington, K. (2004). Social Determinants of Drug Use. Technical Report Number 228. Sydney, NSW: National Drug and Alcohol Research Centre, University of New South Wales.

Sun, Y. (2001). Family Environment and Adolescents' Well-Being Before and After Parents' Marital Disruption: A Longitudinal Analysis. Journal of Marriage and Family 63, 697 - 713, August 2001.

Tugade, M. M., Fredrickson, B. L. \&Barrett, L. F. (2004). Psychological Resilience and Positive Emotional Granularity: Examining the Benefits of Positive Emotions on Coping and Health. Journal of Personality, 72(6), 1161 - 1190, December 2004.

Udida, L.A. Ukway, J.K. \& Ogodo, F.A. (2012). Parental socio-economic background as a determinant of students' academic performance in selected public secondary schools in Calabar Municipal Local Government Area, Cross River State, Nigeria. Journal of Education and Practice, 3(16), 129-135.

UNESCO (nd). Pupil-trained Teacher Ratio. http://uis.unesco.org/en/glossary-term/pupil-trained-teacher-ratio.

UNICEF (2009). The State of the World's Children. New York, NY: UNICEF.

UNICEF (2010). 2010 Global: Progress Evaluation of the UNICEF Education in Emergencies and Post-crisis Transition Programme (EEPCT). https://www.unicef.org/evaluation/index_60830.html

Wallace, S.A. \& Fisher, C.B. (2007). Substance Use Attitudes among Urban Black Adolescents: The Role of Parent, Peer, and Cultural Factors. Journal of Youth Adolescence, 36, 441. https://doi.org/10.1007/s10964006-9099-5 